\title{
Agrobiodiversity conservation enhances food security in subsistence-based farming systems of Eastern Kenya
}

\author{
Simon Wambui Mburu', Gilbert Koskey ${ }^{1}$, Jacinta Malia Kimiti ${ }^{2}$, Omwoyo Ombori ${ }^{3}$, John M. Maingi ${ }^{1}$ \\ and Ezekiel Mugendi Njeru ${ }^{1 *}$
}

\begin{abstract}
Background: Globally, there is great concern about expanding agricultural activities due to their impact in the conservation of agrobiodiversity. African continent is known for its richness in biodiversity. In Kenya, there is a continuous unabated expansion of agriculture into natural habitats due to demographic and economic pressures posing a significant threat to biodiversity. Therefore, there is a need to study biodiversity loss and its regain through practices in agricultural landscapes. In this study, we assessed the status of agrobiodiversity and its contribution to food security in four agroecological zones of Eastern Kenya. Sixty households were sampled from two selected agroecological zones (upper and lower midland zones) in Embu and Tharaka-Nithi counties. Structured questionnaires and checklists were used to collect the data.
\end{abstract}

Results: Thirty-nine crop species were identified dominated by vegetables, fruits, legumes and cereals with relative densities of 28.8, 20.5, 18.3 and 8.3 \%, respectively. Embu Lower Midland and Tharaka-Nithi Lower Midland zones had relatively higher crop species richness of 243 and 240, respectively, and Shannon-Wiener diversity indices $\left(H^{\prime}\right)$ of 3.403 and 3.377, respectively, compared with Embu Upper Midland and Tharaka-Nithi Upper Midland zones with species richness of 229 and 207, respectively, and $H^{\prime}$ of 3.298 and 3.204, respectively.

Conclusions: Households from lower midland zones with high crop diversity and richness were more food secure compared with those from the Upper Midland zones with low crop diversity and richness. These findings suggest that farm production systems with high agrobiodiversity contributed more toward food security among smallholder farmers in the selected sites.

Keywords: Agrobiodiversity, Food security, Biodiversity loss, Smallholder farmers, Kenya

\section{Background}

Agrobiodiversity conservation is vital in attaining sustainable agricultural systems in the context of limited external inputs and mitigating climate change [1]. It comprises of variability and varieties of plants, animals and microorganisms that are important in maintaining critical functions of the agricultural ecosystem [2]. Major threats to natural conservation and food security in Sub-Saharan Africa (SSA) are land degradation

\footnotetext{
*Correspondence: njeruezek@gmail.com

1 Department of Microbiology, Kenyatta University, P.O. Box 43844-00100, Nairobi, Kenya

Full list of author information is available at the end of the article
}

and soil infertility [3]. The widespread food deficit and increasing population pressure in SSA is therefore compelling for an increased sustainable agricultural productivity and poverty alleviation among smallholder farmers. In Kenya, the fundamental component of biodiversity is agrobiodiversity since agriculture is the backbone of the Kenyan economy occupying over $70 \%$ of the productive land [4]. Different studies have shown the importance of agrobiodiversity in agriculture because each species has its role in food chain while the nature of the agricultural environment is dependent on crop diversification $[5,6]$. Agrobiodiversity is crucial for delivery of a wide range of agroecosystem services, which greatly enhances the 
quality of human life [7]. However, human activities have adversely contributed to the loss of biodiversity, thus compromising ecosystem stability [8].

According to FAO [3], about $70 \%$ of the crop genetic diversity and $30 \%$ of livestock breeds have been lost while some are on the verge of extinction. Due to the need for high yielding and uniform crop varieties and animal breeds that have high market demand, most farmers worldwide have abandoned their numerous and diverse types and breeds [9]. Lack of knowledge and poverty are some of the factors that have been attributed to the loss of biodiversity in agriculture in the Sub-Saharan Africa [10]. As a result, community's resilience to harsh environmental conditions has been reduced as evidenced by the present continuous drought, food insecurity and low income. Globally, rich agricultural biodiversity is highly valued and contributes significantly to household income and national food security [11].

Smallholder farmers in most areas such as Eastern Kenya highly depend on crop diversity and livestock enterprises due to the limitation of farm sizes [4]. Embu and Tharaka-Nithi counties are close to the slopes of Mt. Kenya where soil erosion is rampant and hence challenges farming communities who have occupied the steep terrains [12]. Farmers have been attracted by the favorable agricultural conditions (high rainfall that is bimodal) and fertile soils that result in high crop growth rate and yields. The region is rich in plant biodiversity due to high soil productivity potential, vegetation and other soil resources as indicated by a significant number of different crop varieties and land use systems. Households in the region practice mainly subsistence mixed farming that is composed of cultivation of diverse crop varieties and livestock keeping [13]. The cropping systems practiced in most of the household farms include mono-cropping, multiple cropping, intercropping, mixed cropping, strip cropping and agroforestry [14].

Conversely, there is increasing concern over the land quality as farmers over the time have experienced declining crop production [15]. Agricultural sustainability and soil fertility on smallholder farms are determined by land use and management practices [16]. In Eastern Kenya, smallholder farms are characterized by intensive farming with limited agricultural inputs, which has resulted to impoverished soil and reduced crop productivity. To cope with food shortages, over $50 \%$ of the households have been forced to purchase food despite their low-income base [17]. Diversified farm enterprises would help in solving the problem of food insecurity due to unfavorable conditions such as rainfall uncertainty, pest and disease infestation and the high cost of agricultural inputs.

Benefits of agrobiodiversity to the smallholder agroecosystems include risk mitigation where low-input farmers use different crop varieties and livestock to address the risk brought about by diseases, drought, pest and even volatile markets $[18,19]$. Commercialization of native crop varieties, tree products, indigenous fruits, medicinal plants among others can generate income to smallholder farmers, thus improving their living standards [20]. Resource-poor local smallholder farmers also depend entirely on agrobiodiversity for health and nutrition by growing different crop varieties. In addition, it also contributes to ecosystem resilience through enhancing good water and soil management and functional agroecosystems. Countries in Sub-Saharan Africa from the perspective of nutrition, greater agrobiodiversity in agricultural systems have been linked to greater dietary diversity both in farm and village levels [21]. During this study, biodiversity indicators were used to assess the role of crop diversification to food security among the smallholder farmers.

This study therefore aimed at determining agrobiodiversity conservation and its contribution to food security among smallholder farmers in Eastern Kenya. The specific objectives were to determine: (1) the status of agrobiodiversity among smallholder farmers in Lower and Upper Midland zones of Eastern Kenya, (2) the role of agrobiodiversity in food security among smallholder households and (3) the factors affecting agrobiodiversity in the smallholder farming systems in Eastern Kenya.

\section{Methods \\ Site description}

The study was carried out in Embu and Tharaka-Nithi counties in Eastern Kenya (Fig. 1) between May 2015 and August 2015 cropping season. The two counties were selected due to a broad cross section of biodiversity. Embu County is located at the foot of Mt. Kenya at $0.53^{\circ} \mathrm{S}, 37.45^{\circ} \mathrm{E}$ within an elevation of $1100-1500 \mathrm{~m}$ above sea level (a.s.l). The area receives an annual precipitation ranging from 600 to $1800 \mathrm{~mm}$, which is bimodal, and over $55 \%$ of the rainfall in the long season [12]. Temperatures are moderate ranging from 12 to $26{ }^{\circ} \mathrm{C}$. Embu soils are sandy clay in nature characterized by low exchangeable ions and have low percentage nitrogen content (\% N) of $0.23 \%$ [4]. Majority of the households are smallholder farmers with small units of crops and livestock. Dominant crops are maize, beans, soybeans, cowpeas, avocado, bananas, tea and coffee, while livestock include poultry, dairy cattle, sheep and goats. On the other hand, Tharaka-Nithi County is on the southeastern side of Mt. Kenya at $0.30^{\circ} \mathrm{S}, 38.06^{\circ} \mathrm{E}$ and lies at an elevation of 600-1500 m (a.s.l) [22]. During cold seasons, the area has an average temperature of $11{ }^{\circ} \mathrm{C}$, while in the hot seasons, the temperature rises 


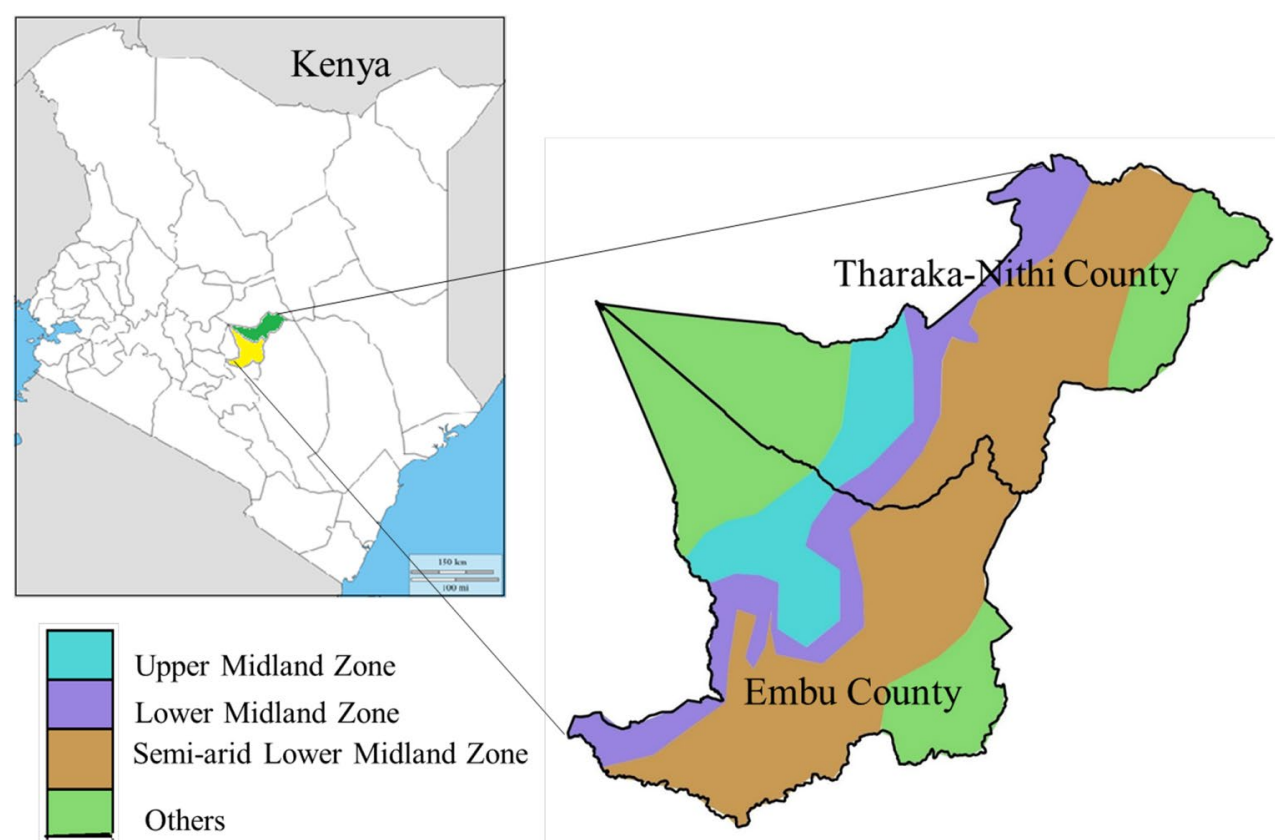

Fig. 1 Map of Kenya showing agroecological zones of Embu and Tharaka-Nithi counties

up to $25^{\circ} \mathrm{C}$. The area is largely semi-arid and receives a bimodal pattern of rainfall, which is $<1000 \mathrm{~mm}$ per year [23]. The county residents are subsistence farmers with intensively managed crop-livestock enterprises and slope cultivation that cover up to $60 \%$ [24]. The agricultural sector is dominated by coffee, tea, bananas, beans, macadamia, sorghum and livestock production that comprises of dairy cattle, goats and sheep.

\section{Data collection}

Structured questionnaires were administered randomly through face-to-face interviews with individual household heads. The interviews focused on the diversity of farming systems, farm characteristics, livestock species, crop species and varieties, major diseases and pests, soil fertility and the type of weeds. However, during the study, more emphasis was given to legumes because of their role in human nutrition (mainly used as grain legumes and vegetables) and biological soil fertility. In each county, the survey was carried out in four agroecological zones (AEZ): Embu Upper Midland (EUM) and TharakaNithi Upper Midland (TUM) zones (1500-2000 m a.s.l), Embu Lower Midland (ELM) and Tharaka-Nithi Lower Midland (TLM) zones (1000-1500 m a.s.l). Sixty households were interviewed in the selected study sites. The sample size was determined following the formula as described by Snedecor and Cochran [25].

$$
n=\frac{4 p q}{(L)^{2}}
$$

where $n$ sample size, $p$ proportion in the target population, $q=1-p$ and $L$ accepted error (5\%). During this study, the target population was the number of households in each zone that was obtained from Ministry of Agriculture under County Agricultural Extension Officer. In Embu County, the target population was 12,844 households. The total households in upper and lower midland zones were 258 households. The calculated sample size was: $P=12,844 / 258=0.0201, q=1-0.0201=0.9671$, $L^{2}=(0.05)^{2}=0.0025$

$$
\begin{aligned}
n= & (4 \times 0.0201 \times 0.9671) / 0.0025=31.5=32 \\
& \text { smallholder farmers }
\end{aligned}
$$

In Tharaka-Nithi County, the target population was 9671 smallholder farmers with 170 households in the upper and lower midland zones. The calculated sample size was: $p=9671 / 170=0.0176, q=1-0.0176=0.9824$, $L^{2}=(0.05)^{2}=0.0025$

$$
\begin{aligned}
& n=(4 \times 0.0176 \times 0.9824) / 0.0025=27.66=28 \\
& \quad \text { smallholder farmers }
\end{aligned}
$$

Stratified sampling was used to represent the livelihood and food security-related variables of the agroecological zones from each county. The size of the zone determined the probability of each sampling unit being selected. Within the zone, sampling of households was carried out by random selection of transects.

The household hunger score (HHS) comprised of items that were asked with a recall period of 3 months 
as described by FAO [3]. The results from HHS delineated households across the three levels of food insecurity, which include food secure, moderate food insecure and severe food insecure. The households' scores were assigned to one of the levels according to Coates et al. [26]. The scores were classified as $0-1$ "little to no hunger in the household," 2-3 "moderate hunger in the household" and 4-6 as "severe hunger in the household."

\section{Data analyses}

Quantitative and qualitative data were generated where Statistical Package for Social Sciences (SPSS) version 22.0 Computer software was used to carry out descriptive analyses. Shannon-Wiener diversity index $\left(H^{\prime}\right)$ and Simpson's index $(D)$ were used to analyze diversity, richness and distribution of crop species in the region [27]. The two indices were applied because they take into account the components of diversity: the species evenness and relative species abundance. Species richness of the entire households was calculated by adding all the species identified across the region [28]. The household hunger scores were converted into percentage [26]. Spearman's rank correlation coefficient was used to establish possible relationships between demographic factors and farm biodiversity. Species relative density, evenness and diversity indices were calculated as follows:

1. Species relative density $=$ All farms individual number of species $\times 100$ /total number of households.

2. Shannon-Wiener index $\left(H^{\prime}\right)=-\sum\left(P_{i}\right) \ln \left(P_{i}\right)$ where $P_{i}=n_{i} / N$, in which $n_{i}$ is the number of individuals of species $i$, while $N$ is the total number of individuals of all species in a sample.

3. Species evenness index, $E=H^{\prime} \log S$ where $H^{\prime}=$ Shannon-Wiener diversity index.

4. Simpson diversity index $(D)=1-\sum\left[n_{i}\left(n_{i}-1\right) / N(N\right.$ $-1)$ ]

where $n$ is the total number of individual species, while $N$ is the total number of all individual species in a sample.

\section{Results}

\section{Status of agrobiodiversity}

Thirty-nine crop species were identified in the 60 smallholder households surveyed. The findings show that farmers had diverse crop enterprise in their farms and majority of the farmers had more than one crop combination (Fig. 2). Maize and common beans were the most dominant crop species grown by 58 and $53 \%$ household, respectively. Cowpea $(41 \%)$ and soybeans $(43 \%)$ were well distributed within the four agroecological zones. Vegetable species were diverse and dominant (46\%). Indigenous vegetables such as amaranthus were observed
(24\%) (Fig. 2). However, millet, groundnuts, oranges and guavas were observed only in one agroecological zone.

Crops maintained by farmers in the study area had diverse uses (Table 1). Legumes, cereals, vegetables, fruits, coffee and tea were dominant and were grown exclusively for commercial purposes. Additionally, Catha edulis, which is a new cash crop in the two counties, was reported by few households (1.4\%). The study identified 23 crop species that were cultivated in the four regions (Fig. 3). Three crop species Cajanus cajan, Ipomoea batatas and Persea americana were only common in TUM, EUM and ELM AEZs. Sorghum bicolor and Mangifera indica were grown in ELM and TLM, while Vigna radiata was found in TUM and ELM. However, some species were present only in one region with very low relative density. Eleusine coracana and Psidium guajava were recorded in ELM and EUM, respectively, and Arachis hypogaea and Citrus sinensis were grown in TLM (Fig. 3).

\section{Crop species diversity}

Agrobiodiversity was assessed using species richness and their relative abundance (species evenness). There was relatively high $H^{\prime}$ of 4.880 in all the sampled categories. ELM zone recorded the highest $H^{\prime}$ of 3.403, TLM $\left(H^{\prime}=3.377\right)$, while upper midland zones recorded relatively lower $H^{\prime}$ (Table 2 ).

There was high diversity of legumes grown in the study sites where majority of the households planted common beans, climbing beans and soybeans. However, cowpeas, pigeon peas and green grams were grown by a few smallholder farmers. The results further indicated that ELM had the highest legume $H^{\prime}$ of 2.000 , followed by TUM $\left(H^{\prime}=1.938\right)$, while TLM and EUM had the lowest diversity indices (Table 3 ).

In the study areas, there were eight commonly cultivated bean types which included climbing and nonclimbing bush-type varieties (Fig. 4). The climbing bean varieties consisted of Gatune, Kithiga, Raila, Mama safi and Muviki, while non-climbing bean varieties included Maasai, Nduriandu (Mwitemania) and Kamucere. Out of the eight varieties, the most common bean variety cultivated in the study area was Maasai with a frequency $(F)$ distribution of $37 \%$, while the least cultivated variety was Kamucere $(F=8 \%)$ (Fig. 4).

\section{Food security}

The findings show that $62 \%$ of the households did not experience food shortage or hunger in the previous season, before the survey. Some households had experienced moderate food shortage ( $25 \%$ ), while others experienced severe hunger (13\%) (Table 4). TUM zone led in food shortage, where over $50 \%$ of the respondents reported 


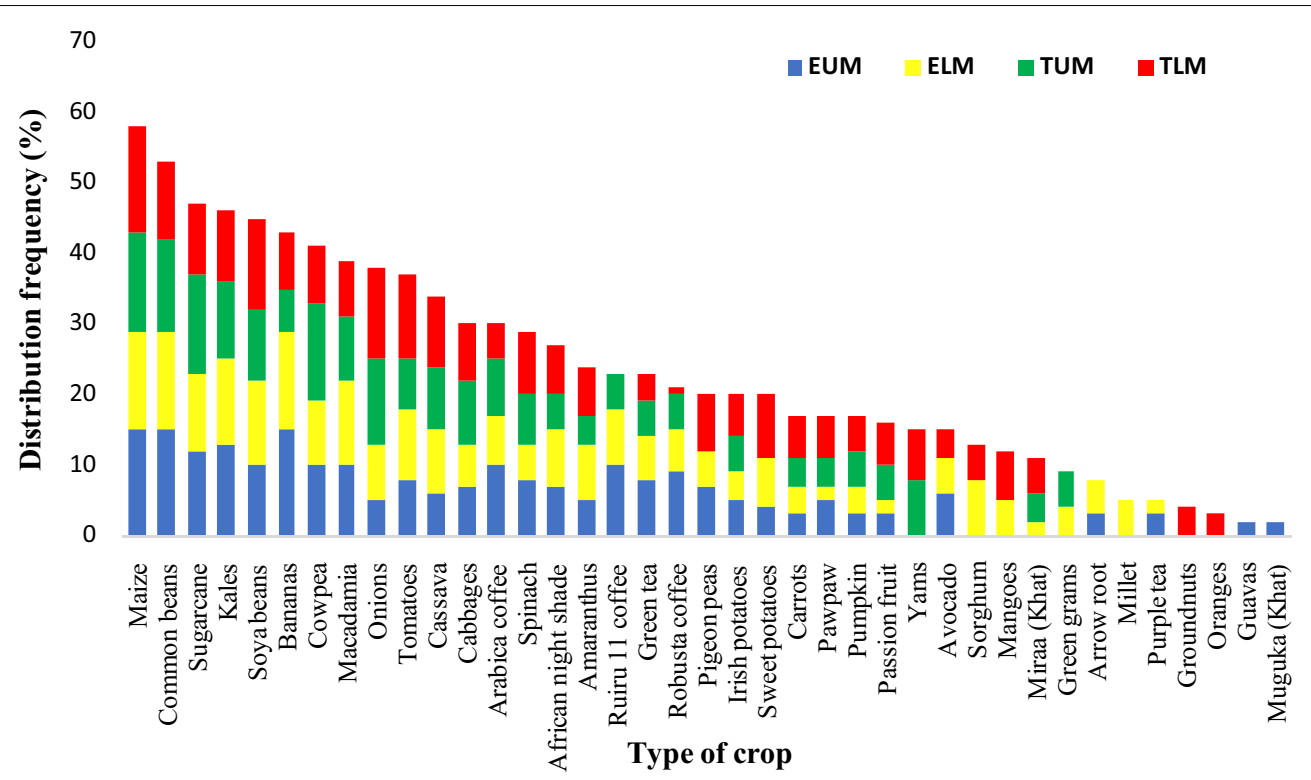

Fig. 2 Crops grown by smallholder farmers in Embu and Tharaka-Nithi counties. TUM Tharaka-Nithi Upper Midland zone, TLM Tharaka-Nithi Lower Midland zone, EUM Embu Upper Midland zone, ELM Embu Lower Midland zone

to have purchased food frequently from the market. ELM was least affected by food shortage (27\%), and there was therefore no severe food shortage recorded (Table 4).

\section{Factors affecting agrobiodiversity}

There existed significant relationships between smallholders' farms diversity and biophysical factors (Table 5). Some of the independent factors such as age and farm size were not significantly related to smallholder farms diversity-dependent variables. Farming years positively influenced $H^{\prime}$ of the total crop species (Table 5), indicating that species diversity increased depending on the number of years the farm had been cultivated. Moreover, the age of the household head had a positive influence on species diversity, showing that those who had been farming for many years registered relatively higher diverse crop species. There was a significant and a weak negative correlation between the level of education of the household head and crop diversity $(r=-0.199, n=60$, $p<0.05$ ) (Table 5).

\section{Discussion}

\section{Agrobiodiversity in smallholder farms}

The findings show that 39 crop species across the region were recorded among the 60 households surveyed. This high species diversity represents the region as a hub of crop species richness among the households. The high crop diversity acts as a supply of subsistence materials to households. Baul et al. [29] reported 53 crop species among the smallholder farmers in Nepal, which demonstrated a high diversity. Crop diversification refers to how the land is equitably allocated to all crops and also increasing the number of crop varieties [30]. In addition, smallholder farmers from rural areas have adapted crop diversification to improve productivity [10].

Different crop combinations in the same household and across the region indicate the level of agrobiodiversity conservation. Depending on nutritional and economic factors, some crop species such as maize and beans dominated with high percentages within the four regions. Maize and beans represented the most preferred type of crops. Traditionally, the two crops are mixed to make a meal and may explain their relative dominance. Migliorini and Vazzana [18] reported that for nutritional purposes, staple foods are given high preference among the farmers for domestic consumption and income. Soybean had a high preference among the household as a substitute for beans and its commercial use in various industries. These findings concur with a similar study carried out in Nepal where smallholder farms were mainly dominated by staple food crops [20].

Some crop species such as P. guajava, A. hypogaea and E. coracana had very low relative density with a presentation in one region. The crops were grown by a small percentage of farmers, indicating that they may be on the verge of extinction. According to Kumba et al. [31], some crops lose value due to factors such as change in climate or human preference and with time become extinct. Some crops such as E. coracana are suitable to the climate in the region but were only present in TLM. Such 
Table 1 Crop species grown by smallholder farmers in selected sites of Eastern Kenya and their relative densities

\begin{tabular}{|c|c|c|c|}
\hline Crop species & Botanical name & Type of crop and its use by farmers & Relative density (\%) \\
\hline Maize & Zea mays $\mathrm{L}$. & Cereal, subsistence and commercial & 6.3 \\
\hline Common bean & Phaseolus vulgaris L. & Grain legume subsistence and commercial & 5.8 \\
\hline Sugarcane & Saccharum officinarum $\mathrm{L}$. & Sugar crop, subsistence and commercial & 5.1 \\
\hline Kale & Brassica oleracea L. var. acephala & Leafy vegetable, subsistence and commercial & 5 \\
\hline Soya bean & Glycine max (L.) Merr. & Oil-seed legume, subsistence and commercial & 4.9 \\
\hline Banana & Musa acuminata L. & Fruit, subsistence and commercial & 4.7 \\
\hline Cowpea & Vigna unguiculata (L.) Walp. & Grain legume, vegetable, subsistence and commercial & 4.5 \\
\hline Macadamia & $\begin{array}{l}\text { Macadamia integrifolia Maiden and } \\
\text { Betche }\end{array}$ & Nut, commercial & 4.2 \\
\hline Onions & Allium cepa L. & Root-bulb vegetable, subsistence and commercial & 4.1 \\
\hline Tomato & Solanum lycopersicum L. & Vegetable, subsistence and commercial & 4.0 \\
\hline Cassava & Manihot esculenta (L.) Crantz & Root-tuber, subsistence and commercial & 3.7 \\
\hline Cabbage & Brassica oleracea L. var. capitata & Leafy vegetable, subsistence & 3.3 \\
\hline Arabica coffee & Coffea arabica L. & Beverage crop, commercial & 3.3 \\
\hline Spinach & Spinacia oleracea L. & Leafy vegetable, subsistence & 3.2 \\
\hline African nightshade & Solanum nigrum L. & Indigenous food vegetables, subsistence & 2.9 \\
\hline Amaranth & Amaranthus dubius $\mathrm{L}$. & Indigenous food vegetables, subsistence & 2.6 \\
\hline Ruiru 11 coffee & Coffea arabica L. & Beverage crop, commercial & 2.5 \\
\hline Green tea & Camellia sinensis (L.) Kuntze & Beverage crop, commercial & 2.5 \\
\hline Robusta coffee & Coffea robusta $\mathrm{L}$. & Beverage crop, commercial & 2.3 \\
\hline Pigeon pea & Cajanus cajan (L.) Mill & Grain legume, subsistence and commercial & 2.2 \\
\hline Irish potato & Solanum tuberosum $\mathrm{L}$. & Root-tuber, subsistence and commercial & 2.2 \\
\hline Sweet potato & Ipomoea batatas (L.) Lam. & Root-tuber, subsistence and commercial & 2.2 \\
\hline Carrot & Daucus carota L. & Root-tuber vegetable, subsistence and commercial & 1.8 \\
\hline Pawpaw & Carica papaya L. & Fruit, subsistence and commercial & 1.8 \\
\hline Pumpkin & Cucurbita pepo L. & Indigenous vegetable, subsistence and commercial & 1.8 \\
\hline Passion fruit & Passiflora edulis Sims & Fruit, subsistence and commercial & 1.7 \\
\hline Yam & Dioscorea villosa $\mathrm{L}$. & Root-tuber, subsistence and commercial & 1.6 \\
\hline Avocado & Persea americana L. & Fruit, subsistence and commercial & 1.6 \\
\hline Sorghum & Sorghum bicolor L. & Cereal, subsistence and commercial & 1.4 \\
\hline Mango & Mangifera indica L. & Fruit, subsistence and commercial & 1.3 \\
\hline Miraa (Khat) & Catha edulis (Vahl) Forssk. Ex Endl. & Commercial $^{\mathrm{a}}$ & 1.2 \\
\hline Green gram & Vigna radiata (L.) R. Wilczek & Grain legume, subsistence and commercial & 1.0 \\
\hline Arrow root & Maranta arundinacea L. & Root-tuber, subsistence and commercial & 0.9 \\
\hline Finger millet & Eleusine coracana (L.) Gaertn. & Cereal, subsistence and commercial & 0.5 \\
\hline Purple tea & Camellia sinensis L. & Beverage crop, commercial & 0.5 \\
\hline Groundnut & Arachis hypogaea L. & Protein oil-seed crop, subsistence and commercial & 0.4 \\
\hline Orange & Citrus sinensis $\mathrm{L}$. & Citrus fruit, subsistence and commercial & 0.3 \\
\hline Guava & Psidium guajava $\mathrm{L}$. & Fruit, subsistence and commercial & 0.2 \\
\hline Khat (Muguka) & Catha edulis (Vahl) Forssk. Ex Endl. & Commercial $^{\mathrm{a}}$ & 0.2 \\
\hline
\end{tabular}

a Considered as a drug in some countries

crops apart from adaptability to climate change, their economic value may contribute to their low score across our study region [32]. When crops are highly susceptible to adverse climate changes and lack of market value, they are replaced with other crops [5].

There was a high diversity of indigenous vegetables and cereals in this region, which may directly help to conserve agrobiodiversity and livelihoods. Despite their high nutritional value, indigenous vegetables grow naturally with no or little inputs and are well adapted to local climatic conditions, which may account for the high dominance. These results are consistent with the report by Sibhatu et al. [7] that smallholder farmers grow diverse crops for food security, which contribute to agrobiodiversity 


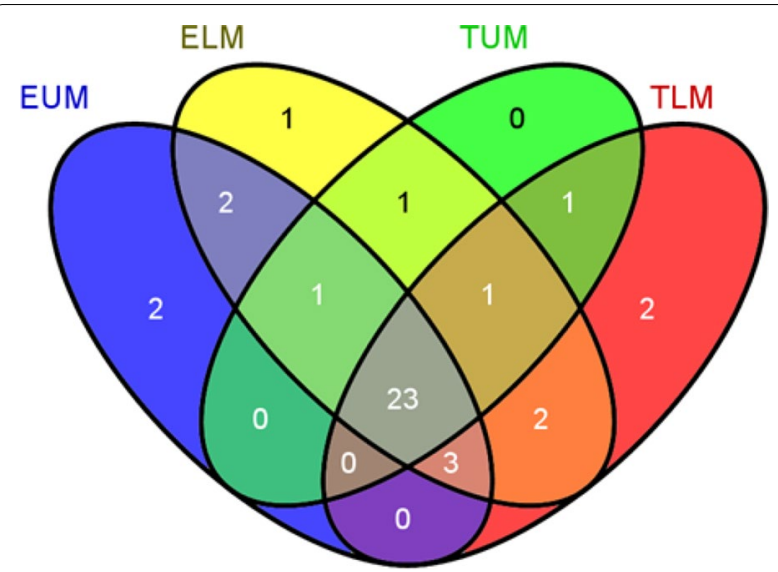

Fig. 3 Venn diagram showing the distribution of different crop species among smallholder farmers in the selected sites of Eastern Kenya. The numerals in the Venn diagram show the number of species distributed across the agroecological zones. TUM Tharaka-Nithi Upper Midland zone, TLM Tharaka-Nithi Lower Midland zone, EUM Embu Upper Midland zone, ELM Embu Lower Midland zone

Table 2 Biodiversity indices of crop species grown by smallholder farmers in the selected study sites of Eastern Kenya

\begin{tabular}{lllll}
\hline Diversity & \multicolumn{2}{l}{ Region } & & \\
\cline { 2 - 5 } & EUM & ELM & TUM & TLM \\
\hline Taxa_S & 31 & 34 & 27 & 32 \\
Individuals & 229 & 243 & 207 & 240 \\
Dominance_D & 0.041 & 0.036 & 0.044 & 0.037 \\
Simpson_1-D & 0.959 & 0.9634 & 0.9559 & 0.9634 \\
Shannon_H & 3.298 & 3.403 & 3.204 & 3.377 \\
Evenness_e^H/S & 0.8724 & 0.883 & 0.9127 & 0.914 \\
\hline
\end{tabular}

TUM Tharaka-Nithi Upper Midland zone, TLM Tharaka-Nithi Lower Midland zone, EUM Embu Upper Midland zone, ELM Embu Lower Midland zone

Table 3 Biodiversity indices of bean species grown in the selected study sites of Eastern Kenya

\begin{tabular}{|c|c|c|c|c|}
\hline \multirow[t]{2}{*}{ Diversity } & \multicolumn{4}{|l|}{ Region } \\
\hline & EUM & ELM & TUM & TLM \\
\hline Taxa_S & 8 & 8 & 8 & 8 \\
\hline Individuals & 46 & 53 & 49 & 47 \\
\hline Dominance_D & 0.187 & 0.144 & 0.157 & 0.167 \\
\hline Simpson_1-D & 0.812 & 0.855 & 0.843 & 0.833 \\
\hline Shannon_H & 1.833 & 2.000 & 1.938 & 1.910 \\
\hline Evenness_e^H/S & 0.7813 & 0.921 & 0.8683 & 0.8439 \\
\hline
\end{tabular}

TUM Tharaka-Nithi Upper Midland zone, TLM Tharaka-Nithi Lower Midland zone, EUM Embu Upper Midland zone, ELM Embu Lower Midland zone

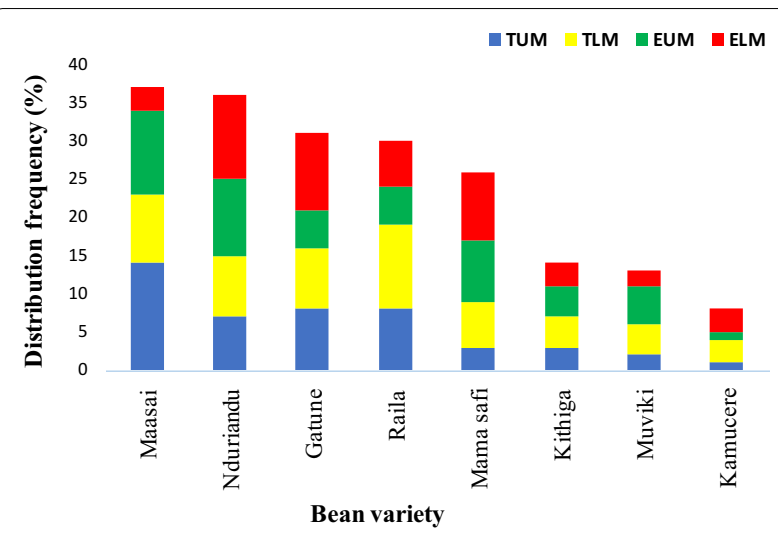

Fig. 4 Frequency distribution (\%) of different common bean varieties grown in selected sites of Eastern Kenya. TUM Tharaka-Nithi Upper Midland zone, TLM Tharaka-Nithi Lower Midland zone, EUM Embu Upper Midland zone, ELM Embu Lower Midland zone

Table 4 Households food shortage and the level of severity (\%) among smallholder farmers in selected sites of Eastern Kenya

\begin{tabular}{llcc}
\hline $\begin{array}{l}\text { Agroecological } \\
\text { zone }\end{array}$ & Food shortage (\%) & \multicolumn{2}{c}{ Severity of food shortage } \\
\cline { 3 - 4 } & & Moderate (\%) & Severe (\%) \\
\hline EUM & 40 & 67 & 23 \\
ELM & 27 & 100 & 0 \\
TUM & 53 & 63 & 27 \\
TLM & 33 & 80 & 20 \\
Overall (all zones) & 38 & 25 & 13 \\
\hline
\end{tabular}

conservation. However, it is crucial to note that majority of these crops are grown for domestic consumption. The main reason according to Damghani et al. [21] is that farmers have limited land for crop cultivation.

Although some differences were noted between the agroecological zones farmers managed a high level of crop biodiversity. ELM had the highest index $\left(H^{\prime}\right)$ compared with other agroecological zones. Households from ELM had limited farm sizes that were fragmented to accommodate different crop species to spread the risk in case of natural calamities such as drought. Both lower midland zones had higher crop diversity since farmers sought to maintain diverse crops to mitigate against various uncertainties, especially unpredictable climatic conditions. The crop diversity found represented a high level of species richness which is supported by other studies on agrobiodiversity [33]. 
Table 5 Spearman's correlation coefficient $(r)$ between demographic factors and biodiversity

\begin{tabular}{|c|c|c|c|c|c|c|}
\hline Factors & $\begin{array}{l}\text { Age of household } \\
\text { head }\end{array}$ & $\begin{array}{l}\text { Education } \\
\text { level }\end{array}$ & $\begin{array}{l}\text { Farm } \\
\text { years }\end{array}$ & $\begin{array}{l}\text { Total farm } \\
\text { size (acres) }\end{array}$ & $\begin{array}{l}\text { Shannon diversity } \\
\text { index }\left(H^{\prime}\right)\end{array}$ & $\begin{array}{l}\text { Simpson diversity } \\
\text { index (D) }\end{array}$ \\
\hline $\begin{array}{l}\text { Age of household } \\
\text { head }\end{array}$ & 1 & & & & & \\
\hline Education level & $-0.398^{* *}$ & 1 & & & & \\
\hline Farm years & $-0.489^{* *}$ & $0.372^{* *}$ & 1 & & & \\
\hline Total farm size (acres) & $0.383^{* *}$ & -0.099 & $0.567^{* *}$ & 1 & & \\
\hline $\begin{array}{l}\text { Shannon diversity } \\
\text { index }\left(H^{\prime}\right)\end{array}$ & 0.168 & $-0.199^{*}$ & $0.056^{*}$ & 0.019 & 1 & \\
\hline $\begin{array}{l}\text { Simpson diversity } \\
\text { index (D) }\end{array}$ & -0.192 & 0.137 & -0.190 & -0.113 & $-0.822^{* *}$ & 1 \\
\hline
\end{tabular}

* Correlation is significant at the 0.05 level (two-tailed)

** Correlation is significant at the 0.01 level (two-tailed)

The current study recorded low diversity in TUM although the region is on the slope of Mt. Kenya surrounded by natural forest. The region was dominated by tea and coffee, which are high value crops. Similarly, single species dominance for commercial and economic purposes has been reported in Kenya [28]. The high variation observed in the diversity between different agroecological zones can be explained by a change in altitude and climatic differences. Other studies on agrobiodiversity noted that there was a sharp decline in crop diversity with an increase in altitude [34]. However, site location cannot exclusively determine crop diversity due to climatic factors.

Grain legumes enhance soil fertility through biological nitrogen fixation and have a high nutritional value, which may account for the high diversity recorded in Eastern Kenya. This observation was consistent with the findings of Figliuolo and Cerbino [35] and Torrico [36] in which subsistence farmers cultivate a high diversity of legumes and vegetables, which contribute directly to livelihoods, and conservation of agrobiodiversity. Common bean recorded the highest diversity of up to eight species. The TLM region, which recorded the highest bean diversity and richness, had the highest percentage of households growing different varieties of common beans. In contrary, farmers had more interest in some specific bean varieties such as Maasai in TUM region, thus the low bean diversity recorded in the area.

The Maasai and Nduriandu bean varieties were evidently the most preferred by farmers in the selected sites of Eastern Kenya. Farmers reported that the two varieties were high yielding and resistant to drought, pests and diseases. On the other hand, Kamucere was the least preferred bean variety and was only grown by a few farmers. Kamucere is one of the new bean varieties introduced recently into the area [13]. According to Figliuolo and Cerbino [35], farmers avoid bean varieties, which are not compatible with the local conditions, and this might explain the low percentage of some bean varieties in the study sites. Additionally, non-cultivation of a species by farmers was driven by a range of factors including lack of seeds, marketability, consumer preferences and lack of sufficient land [32].

\section{Agrobiodiversity contribution to food security}

The smallholder farming community depends on the farm produce and grows different crop varieties to meet their daily dietary needs [37]. Majority of households in the upper midland zones had their farms dominated by cash crops and hence depended mostly on purchased food supplies. Accordingly, TUM recorded the lowest $H^{\prime}$ and richness, making farmers more vulnerable to food insecurity in case of unpredictable climate conditions. Species diversity according to Sibhatu et al. [7] was considered as a valuable tool for food security and ecological stability. On the other hand, ELM recorded high crop species diversity and low scores of food insecurity. High species diversity contributes to food security, and hence, the region did not record severe food shortage. Anjichi et al. [30] reported that smallholder farmers grow diverse crops to supplement their nutritional requirements, which is in line with the current study. Although households reported that they experience hunger occasionally, a study in Kisii, Kenya, showed that diversified crops were less risky economically than monocultures and could produce substantial yields [31]. FAO [3] reported that in developing countries about $50 \%$ of smallholder farmers are food insecure. Future food security strategies, particularly for small-scale farmers, will need a sustainable use of biodiversity in agriculture through optimizing the limited available resources [8].

Crop diversity increased with increase in the number of farming years. This diversity may be due to farming experience and value for traditional crop diversity [14]. Upper 
midlands farmers reported low crop diversity and had the least number of farming years. The region is situated on the slopes of Mt. Kenya where the majority of households settled recently after occupying the area around the Mt. Kenya forest. Unlike in the lower midlands with many indigenous crops, upper midlands were dominated by cash crops. According to Baul et al. [29], overdominance by individual crop species among the households is a threat to agrobiodiversity since only limited number of crop varieties can be grown at a time.

Positive correlation between crop diversity and age of household heads shows contribution of farmers towards crop diversification [9]. The household heads were the sole decision makers regarding crops grown where elderly people had high preference for indigenous crops for nutritional and medicinal purposes [24]. Zingore et al. [33] recorded similar results in Zimbabwe where elderly smallholder farmers put more emphasis on traditional crop varieties.

\section{Conclusions}

Thirty-nine crop species were identified. Lower midland zones were found to have a higher crop species diversity and food secure compared with upper midland zones. Households whose farms were low on crop diversity and richness were more food insecure compared with households with high crop diversity and richness. We thus conclude that increased diversity in smallholder farms could contribute significantly towards food security and income generation. Future research should focus on the role of agrobiodiversity conservation and different cropping patterns on food security. There is a need to undertake policy reforms that target smallholder farmers and create awareness on the significance of agrobiodiversity.

\section{Abbreviations}

AEZ: agroecological zones; D: Simpson's index; ELM: Embu Lower Midland: EUM: Embu Upper Midland; F: frequency; FAO: The Food and Agriculture Organization; $H^{\prime}$ : Shannon-Wiener diversity index; RF: relative frequency; TLM: Tharaka-Nithi Lower Midland; TUM: Tharaka-Nithi Upper Midland.

\section{Authors' contributions}

JMK, OO, JMM and EMN conceived and designed the research and data collection tools and participated in drafting the manuscript. SWM and GK collected the data, participated in data analyses and wrote the manuscript. EMN performed data analyses. All authors read and approved the final manuscript.

\footnotetext{
Authors' information

Simon Wambui Mburu is a MSc graduate in Environmental Microbiology from the Department of Microbiology, Kenyatta University (KU). His research focus is on biological soil fertility, agroecology and food security issues. Gilbert Koskey is a MSc graduate in Environmental Microbiology from the Department of Microbiology, KU. His research interests include biological nitrogen fixation in legumes and sustainable agriculture. Dr. Jacinta Malia Kimiti is a Lecturer and Dean, School of Environment and Natural Resources Management, South Eastern Kenya University, Kitui, Kenya. Her research focus includes soil biology and fertility, community-based participatory research and use of bioresources in agriculture. Dr. Omwoyo Ombori is a Lecturer in Plant Biotechnology and
}

Chairman of the Department of Plant Sciences, KU. His main research interests include plant physiology, plant biotechnology and application of low-cost technologies in agriculture. Dr. John M. Maingi is a Lecturer in Agricultural and Environmental Microbiology, and Chairman of the Department of Microbiology, KU. His main areas of interest include plant-microbe interactions and application of beneficial microorganisms in agriculture. Dr. Ezekiel Mugendi Njeru is a Lecturer and a Researcher in Agricultural and Soil Microbiology in the Department of Microbiology, KU. His main research interests include plant-microbe interactions in agricultural landscapes, agrobiodiversity and food security.

\section{Author details}

${ }^{1}$ Department of Microbiology, Kenyatta University, P.O. Box 43844-00100, Nairobi, Kenya. ${ }^{2}$ Department of Forestry and Land Resources Management, South Eastern Kenya University, P.O. Box 170-90200, Kitui, Kenya. ${ }^{3}$ Department of Plant Sciences, Kenyatta University, P.O. Box 43844-00100, Nairobi, Kenya.

\section{Acknowledgements}

The authors express their sincere gratitude to RUFORUM for supporting this study and participating households for their cooperation, patience and time during the collection of the data.

\section{Competing interests}

The authors declare that they have no competing interests.

\section{Availability of supporting data}

All data generated or analyzed during this study are available from the corresponding author on reasonable request.

\section{Consent for publication}

All authors consent to the publication of this manuscript in its entirety.

\section{Ethical approval and consent to participate}

All smallholder farmers interviewed voluntarily participated in this study and approved the publication of these findings. The county directors of agriculture from the two counties granted permission for this research to be undertaken in the two regions.

\section{Funding}

This work was funded by the Regional Universities Forum for Capacity Building in Agriculture (RUFORUM) 5th Graduate Research Grant (GRG), Grant No. RU 2014 GRG-102.

Received: 14 April 2016 Accepted: 1 September 2016 Published online: 15 September 2016
References

1. Costanzo A, Bàrberi P. Functional agrobiodiversity and agroecosystem services in sustainable wheat production. A review. Agron Sustain Dev. 2014;34(2):327-48.

2. Segnon AC, Achigan-Dako EG. Comparative analysis of diversity and utilization of edible plants in arid and semi-arid areas in Benin. J Ethnobiol Ethnomed. 2014;10(1):1.

3. FAO. The state of food insecurity in the world. Meeting the 2015 international hunger targets: taking stock of uneven progress. 2015. http://www. fao.org/3/a-i4646e/index.html. Accessed 5 Apr 2016.

4. Ng'endo M, Keding GB, Bhagwat S, Kehlenbeck K. Variability of on-farm food plant diversity and its contribution to food security: a case study of smallholder farming households in Western Kenya. Agroecol Sust Food. 2015;39(10):1071-103.

5. Bongers G, Fleskens L, Van de Ven G, Mukasa D, Giller KE, Van Asten P. Diversity in smallholder farms growing coffee and their use of recommended coffee management practices in Uganda. Exp Agric. 2015;51(4):594-614.

6. Kremen C, lles A, Bacon CM. Diversified farming systems: an agroecological, systems-based alternative to modern industrial agriculture. Ecol Soc. 2012;17(4):1-19. 
7. Sibhatu KT, Krishna VV, Qaim M. Production diversity and dietary diversity in smallholder farm households. Proc Natl Acad Sci. 2015;112(34):10657-62.

8. Thrupp LA. Linking agricultural biodiversity and food security: the valuable role of agrobiodiversity for sustainable agriculture. R Inst Int Aff. 2000;76(2):283-97.

9. Zimmerer KS. The compatibility of agricultural intensification in a global hotspot of smallholder agrobiodiversity (Bolivia). Proc Natl Acad Sci. 2013;110(8):2769-74.

10. Wiehle M, Goenster S, Gebauer J, Mohamed SA, Buerkert A, Kehlenbeck K. Effects of transformation processes on plant species richness and diversity in homegardens of the Nuba Mountains, Sudan. Agrofor Syst 2014;88(3):539-62.

11. Mendez VE, Bacon CM, Olson M, Morris KS, Shattuck A. Agrobiodiversity and shade coffee smallholder livelihoods: a review and synthesis of ten years of research in Central America. Prof Geogr. 2010;62(3):357-76.

12. Jaetzold R, Schmidt H, Hornetz B, Shisanya C. Farm management handbook of Kenya. Natural conditions and farm information. Vol. II, Part C, Eastern Province. Nairobi: Ministry of Agriculture/GTZ; 2006.

13. Ramaekers L, Micheni A, Mbogo P, Vanderleyden J, Maertens M. Adoption of climbing beans in the Central Highlands of Kenya: an empirical analysis of farmers' adoption decisions. Afr J Agric Res. 2013:8(1):1-9.

14. Labeyrie V, Rono B, Leclerc C. How social organization shapes crop diversity: an ecological anthropology approach among Tharaka farmers of Mount Kenya. Agric Hum Values. 2014;31(1):97-107.

15. Hadgu KM, Rossing WA, Kooistra L, van Bruggen AH. Spatial variation in biodiversity, soil degradation and productivity in agricultural landscapes in the highlands of Tigray, Northern Ethiopia. Food Secur. 2009; (1):83-97.

16. Allen T, Prosperi P, Cogill B, Flichman G. Agricultural biodiversity, social-ecological systems and sustainable diets. Proc Nutr Soc. 2014;73(4):498-508

17. Achonga BO, Akuja TE, Kimatu JN, Lagat JK. Implications of crop and livestock enterprise diversity on household food security and farm incomes in the Sub Saharan region. Glob Inst Res Educ. 2015;4(2):125-9.

18. Migliorini P, Vazzana C. Biodiversity indicators for sustainability evaluation of conventional and organic agro-ecosystems. Ital J Agron. 2007:2(2):105-10

19. Njeru EM. Crop diversification: a potential strategy to mitigate food insecurity by smallholders in Sub-Saharan Africa. J Agric Food Syst Commun Dev. 2013;3(4):63-9.

20. Enjalbert J, Dawson JC, Paillard S, Rhoné B, Rousselle Y, Thomas M, Goldringer I. Dynamic management of crop diversity: from an experimental approach to on-farm conservation. C R Biol. 2011;334(5):458-68.

21. Damghani AM, Koocheki A, Moghaddam PR, Mohallati MN. Evaluation of agrobiodiversity and its effects on the sustainability of a wheat-cotton cropping system in Khorassan. Environ Sci. 2007:4(3):61-8.

22. Njeru EM, Maingi JM, Cheruiyot R, Mburugu GN. Managing soybean for enhanced food production and soil bio-fertility in smallholder systems through maximized fertilizer use efficiency. Int J Agric For. 2013;3(5):191-7.
23. Recha CW, Makokha GL, Traore PS, Shisanya C, Lodoun T, Sako A. Determination of seasonal rainfall variability, onset and cessation in semi-arid Tharaka district, Kenya. Theor Appl Climatol. 2012;108(3-4):479-94.

24. Mairura FS, Mugendi DN, Mwanje JI, Ramisch JJ, Mbugua PK, Chianu JN. Scientific evaluation of smallholder land use knowledge in Central Kenya. Land Degrad Dev. 2008;19(1):77-90.

25. Snedecor GW, Cochran WG. Statistical methods. 8th ed. Ames: lowa State University Press lowa; 1989.

26. Coates J, Swindale A, Bilinsky P. Household Food Insecurity Access Scale (HFIAS) for measurement of food access: indicator guide. Washington, DC: Food and Nutrition Technical Assistance Project, Academy for Educational Development; 2007.

27. Magurran AE. Measuring biological diversity. Oxford: Wiley; 2013.

28. Mullah CJ, Totland Ø, Klanderud K. Recovery of plant species richness and composition in an abandoned forest settlement area in Kenya. Restor Ecol. 2012;20(4):462-74.

29. Baul TK, Tiwari KR, Ullah KA, McDonald MA. Exploring agrobiodiversity on farm: a case from Middle-Hills of Nepal. Small-Scale For. 2013;12(4):611-29.

30. Anjichi VE, Muasya RM, Gohole LS, Rao NK, Muui CW. Genetic biodiversity assessment and local seed systems of maize landraces among smallholder farmers in Western Kenya. Afr Crop Sci Conf Proc 2005;7(3):1335-40.

31. Kumba JK, Wegulo F, Otieno J. The impact of socio-economic characteristics on cash and food crop production: implications on household food situation in Kisii Central Sub-County, Kenya. J Econ Sust Dev. 2015:6:147-53.

32. Bahadur KC, Pant LP, Fraser ED, Shrestha PK, Shrestha D, Lama A. Assessing links between crop diversity and food self-sufficiency in three agroecological regions of Nepal. Reg Environ Change. 2016;16(5):1239-51.

33. Zingore S, Tittonell P, Corbeels M, Van Wijk MT, Giller KE. Managing soil fertility diversity to enhance resource use efficiencies in smallholder farming systems: a case from Murewa District, Zimbabwe. Nutr Cycl Agroecosyst. 2011;90(1):87-103.

34. Das T, Das AK. Conservation of plant diversity in rural homegardens with cultural and geographical variation in three districts of Barak Valley, Northeast India. Econ Bot. 2015;69(1):57-71.

35. Figliuolo G, Cerbino D. Agro-biodiversity spatial assessment and genetic reserve delineation for the Pollino National Park (Italy). Nat Resour. 2014:5:308-21.

36. Torrico JC. Agrobiodiversity assessment in the Atlantic Rainforest region of Rio de Janeiro. Agro-Ciencia. 2010;2(1):228-36.

37. Bonnin C, Turner S. Livelihood vulnerability and food security among upland ethnic minorities in Northern Vietnam. Kasar Philipp J Third World Stud. 2011;26(1-2):324-40.

\section{Submit your next manuscript to BioMed Central and we will help you at every step:}

- We accept pre-submission inquiries

- Our selector tool helps you to find the most relevant journal

- We provide round the clock customer support

- Convenient online submission

- Thorough peer review

- Inclusion in PubMed and all major indexing services

- Maximum visibility for your research

Submit your manuscript at www.biomedcentral.com/submit
BioMed Central 